\title{
Correction to: A Physical-Layer Key Distribution Mechanism for loT Networks
}

\author{
Mohanad Alhasanat $^{1} \cdot$ Saud Althunibat ${ }^{2} \cdot$ Khalid A. Darabkh $^{3} \cdot$ Abdullah Alhasanat $^{1,4} \cdot$ Moath Alsafasfeh $^{1}$
}

Published online: 28 March 2019

(C) Springer Science+Business Media, LLC, part of Springer Nature 2019

\section{Correction to: Mobile Netw Appl https://doi.org/10.1007/s11036-019-01219-5}

The original version of this article unfortunately contained mistakes in the author group and affiliation sections. Author Khalid A. Darabkh's surname was mispelled as "Darabkeh" and his affiliation should be updated to "Computer Engineering Department, School of Engineering, The University of Jordan".

The original article has been corrected.

Publisher's Note Springer Nature remains neutral with regard to jurisdictional claims in published maps and institutional affiliations.

The online version of the original article can be found at https://doi.org/ 10.1007/s11036-019-01219-5

Mohanad Alhasanat

mohanadhasanat@ahu.edu.jo

Saud Althunibat

saud.althunibat@ahu.edu.jo

Khalid A. Darabkh

k.darabkeh@ju.edu.jo

Abdullah Alhasanat

abad@ahu.edu.jo; a.ismail@unizwa.edu.om

Moath Alsafasfeh

moath.alsafasfeh@ahu.edu.jo
Department of Computer Engineering, Al-Hussein Bin Talal University, Ma'an, Jordan

2 Department of Communications Engineering, Al-Hussein Bin Talal University, Ma'an, Jordan

3 Computer Engineering Department, School of Engineering, The University of Jordan, Amman 11942, Jordan

4 Department of Electrical and Computer Engineering, College of Engineering and Architecture, University of Nizwa, P.O. 33 Postal Code 616, Nizwa, Oman 